\title{
Increased symptoms of post-traumatic stress in school students soon after the start of the COVID-19 outbreak in China
}

\author{
Hanmei Xu ${ }^{1 \dagger}$, Hang Zhang ${ }^{1 \dagger}$, Lijuan Huang ${ }^{1}$, Xiaolan Wang ${ }^{1}$, Xiaowei Tang ${ }^{1}$, Yanping Wang ${ }^{1}$, Qingqing Xiao ${ }^{1}$, \\ Ping Xiong ${ }^{2}$, Rongqiu Jiang ${ }^{3}$, Jie Zhan ${ }^{4}$, Fang Deng ${ }^{5}$, Mingya Yu ${ }^{6}$, Dong Liu', Xuejun Liư ${ }^{8}$, Chunli Zhang ${ }^{9}$, \\ Wenjun Wang ${ }^{10}$, Lu Li ${ }^{11}$, Hongmei Cao ${ }^{12}$, Wenchao Zhang ${ }^{13}$, Hongping Zhou ${ }^{14}$, Wo Wang ${ }^{15}$ and Li Yin ${ }^{1,16^{*}}$ (D)
}

\begin{abstract}
Background: The outbreak of Coronavirus Disease 2019(COVID-19) caused psychological stress in Chinese adults population. But we are unaware of whether the pandemic causes psychological stress on children.

Methods: We used the Children's Impact of Event Scale questionnaire (CRIES-13) to investigate the degree of Posttraumatic Stress (PTSD) symptoms caused by the pandemic in students selected from schools in Sichuan, Jiangsu, Henan, Yunnan, and Chongqing provinces of China.

Results: A total of 7769 students(3692 male and 4077 female), aged 8-18years, were enrolled in the study, comprising 1214 in primary schools, 2799 in junior high schools and 3756 in senior high schools. A total of 1639 students (21.1\%) had severe psychological stress reactions. A large proportion of senior high school students (23.3\%) experienced severe psychological stress, and they had the highest median total CRIES-13 score. Female students were more likely to experience severe psychological stress and had higher median CRIES-13 total scores than males.
\end{abstract}

Conclusion: COVID-19 has placed psychological stresses on primary and secondary school students in China. These stresses are more likely to reach severe levels among female students and senior high school students.

Keywords: Post-traumatic stress, COVID-19, School students, CRIES-13, Stress, China

\section{Background}

Studies have shown an increased incidence of posttraumatic stress in survivors of large-scale disasters compared with the general population [1-4]. Disasters can be defined as destructive occurrences that disrupt and overwhelm entire communities and affect millions worldwide in a given year [5]. Children who have

\footnotetext{
* Correspondence: yli009@163.com

${ }^{\dagger}$ Hanmei Xu and Hang Zhang contributed equally to this work.

'Mental Health Center, West China Hospital of Sichuan University, No. 28 South Dianxin Street, Chengdu 610041, Sichuan, China

${ }^{16}$ Institute for System Genetics, Frontiers Science Center for Disease-related Molecular Network, Chengdu 610041, Sichuan, China

Full list of author information is available at the end of the article
}

experienced disasters are more vulnerable than adults to mental and psychological disorders, including posttraumatic stress disorder (PTSD) [6-8]. Disasters can severely affect their emotional status, resulting in stress reactions that are different from those experienced by adults. Unlike adults who are able to regulate their emotions, children are more likely to limit or suppress their emotions $[9,10]$. In addition, children may develop serious psychological and mental illnesses that occur sooner and last longer than those in adults [11-13]. And there is ample evidence of gender differences in posttraumatic symptomatology and women are found more likely to develop symptoms than men [3].

(c) The Author(s). 2021 Open Access This article is licensed under a Creative Commons Attribution 4.0 International License, which permits use, sharing, adaptation, distribution and reproduction in any medium or format, as long as you give appropriate credit to the original author(s) and the source, provide a link to the Creative Commons licence, and indicate if changes were made. The images or other third party material in this article are included in the article's Creative Commons licence, unless indicated otherwise in a credit line to the material. If material is not included in the article's Creative Commons licence and your intended use is not permitted by statutory regulation or exceeds the permitted use, you will need to obtain permission directly from the copyright holder. To view a copy of this licence, visit http://creativecommons.org/licenses/by/4.0/ The Creative Commons Public Domain Dedication waiver (http://creativecommons.org/publicdomain/zero/1.0/) applies to the data made available in this article, unless otherwise stated in a credit line to the data. 
In the twenty-first century, a number of infectious diseases have challenged global public health [14].

During the epidemic of severe acute respiratory syndrome in February 2003, many adult patients developed post-traumatic stress symptoms, PTSD, anxiety, depression, and other mental illnesses [15-18]. The current Coronavirus Disease 2019(COVID-19) pandemic also has constituted a global public health disaster [19]. After COVID-19 outbreak in China, our governments issued the first-level public health alert and recommended that all citizens staying at home [20]. The Ministry of Chinese Education estimated that more than 220 million children and adolescents were confined to their homes. In such crisis time, it is necessary to explore whether the COVID-19 pandemic would cause psychological stress on children and adolescents.

Therefore, we investigated the prevalence of posttraumatic stress symptoms in primary and secondary school students from several provinces and regions in China at one month after the start of the COVID-19 outbreak in order to elucidate the effects of the pandemic on the psychological stress in children and adolescents.

\section{Methods}

\section{Subjects}

We recruited 7769 students, from those in first grade of primary school (8 years) to those in the third grade of senior high school (18 years), in Sichuan(6727 students, 2 elementary school, 3 middle school), Jiangsu(767 students, 3 elementary school,1 middle school), Shandong(159 students, 1 elementary school,1 middle school), Henan(10 students, 1 elementary school), Yunnan(43 students, 1 middle school), and Chongqing(63 students, 2 elementary school). Participants were stratified into primary school students (grades1-6), junior high school students (grades7-9), and senior high school students (grades10-12). We excluded students with a history of substance abuse and those suffering from mental illnesses (totally $4.5 \%$ ), as well as those who could not understand the questionnaire.

The minimal sample size required for this study was calculated based on the typical sample size for questionnaire-based surveys of the occurrence of posttraumatic stress after disasters. Based on a PTSD prevalence of $32.2 \%$ in China after the outbreak of COVID-19 [19], we calculated a minimal sample of 2097 for a power of 0.8 , type I error of 0.05 and allowable error of 0.02 . We increased this by $10 \%$ to 2330 to compensate for missing or uncooperative participants. Ultimately, our sample was much larger (7769).

\section{Measurement}

Between 1 February 20 and 1 March 12,020, approximately one month after the outbreak of COVID-19 in China, we collected demographic data including age, sex, grade, family structure, occupation of parents and family members, etc. Psychopathological data was collected using the Children's Revised Impact of Event Scale (CRIES) [21]. After obtaining the informed consent of the participants and their parents, the questionnaire were distributed by parents. Questionnaires couldn't be submitted until they completed all questions, so there is no missing value in our sample.

The CRIES-13 measures symptoms of intrusion (4 items), avoidance (4 items), and arousal (5 new items). Answer item is set as "not at all", "rarely", "sometimes", and "often" $[21,22]$. The CRIES-13 total score is used to judge the severity of the psychological impact caused by a traumatic event. A total score $\geq 30$ is considered to indicate severe psychological stress [22-24].

\section{Statistical analysis}

All statistical analyses were performed using SPSS 25.0(IBM, Armonk, NY, USA), and the significance level was set as $\alpha=0.05$.We analyzed participant data and compared CRIES-13 scores across groups using the Chisquared, Mann-Whitney U, and Kruskal-Wallis $\mathrm{H}$ tests. Post-hoc comparisons were conducted after adjusting the level of significance using Bonferroni correction.

We performed stepwise binary logistic regression using the forward likelihood ratio (LR) method in order to identify factors influencing perceived stress. We considered the influence of sex, age, grade, family structure, occupation of parents, past history of psychological illness (history of psychological consultations or use of psychotropic drug therapy), recent diagnosis of COVID19, and exposure to coronavirus infection within the previous 30 days. Questions about infection exposure addressed the number of visits to Hubei province and surrounding areas, contact with patients diagnosed with COVID-19, incidence/occurrence of cold, fever, cough, nasal congestion, runny nose, sore throat, and diarrhea, and participation in large gatherings, such as dinner parties. Exposure was also assessed based on contact with family members who were doctors and frontline workers, as well as relatives within three generations who had been diagnosed with COVID-19 or were suspected of COVID-19. We also included data on whether participants had received therapy against COVID-19, or had fever and other mild symptoms.

In order to reduce information bias, we used blind method (blinded to data analyst) to collect data, and two psychiatrists carried out strict quality control of the questionnaire. Because we strictly enforce the inclusion criteria and exclusion criteria, there are such restrictions on participants to avoid confounding bias due to other diseases. At the same time, our study did logical regression analysis to minimize the impact of confounding factors. 


\section{Results}

Demographic and clinical characteristics of subjects Our survey included a total of 7769 students (4077 female) from 5 different provinces in China (Table 1). All participants were between 8 and 18 years old (median 15 years), and were stratified into three groups based on their grade: primary school students (15.62\%, median age 11 years), junior high school students (36.03\%, median age 13 years), and senior high school students (48.35\%, median age 16 years). In total, 24 participants (13 males and 11 females) were diagnosed with COVID-19, and 27 (16 males and 11 females) were suspected of being infected with the disease. There were significant differences in gender distribution among different $\operatorname{grades}\left(x^{2}=32.234, p<0.001\right)$.

We collected information about the family structure and occupation of the parents of all participants. A large proportion of participants lived in three-generational households (35.6\%) and in families with three individuals including the respondent (33.6\%), and lived with single

Table 1 Demographic characteristics of school students, stratified by sex and grade

\begin{tabular}{|c|c|c|c|c|c|c|c|c|c|c|}
\hline \multirow[b]{2}{*}{ Characteristic } & \multirow{2}{*}{$\begin{array}{l}\text { Total } \\
(n= \\
7769)\end{array}$} & \multicolumn{2}{|l|}{ Sex } & \multirow[b]{2}{*}{$\mathrm{Z} / \times 2$} & \multirow[b]{2}{*}{$\mathbf{p}$} & \multicolumn{3}{|l|}{ Grade } & \multirow[b]{2}{*}{$H / x 2$} & \multirow[b]{2}{*}{$\mathrm{p}$} \\
\hline & & $\begin{array}{l}\text { Male } \\
(n=3692)\end{array}$ & $\begin{array}{l}\text { Female } \\
(n=4077)\end{array}$ & & & $\begin{array}{l}\text { Primary } \\
(n= \\
906)\end{array}$ & $\begin{array}{l}\text { Junior } \\
\text { High } \\
(n= \\
2799)\end{array}$ & $\begin{array}{l}\text { Senior } \\
\text { High } \\
(n= \\
3756)\end{array}$ & & \\
\hline Median age (years) & 15 & 15 & 15 & -1.910 & $0.056^{*}$ & 11.00 & 13.00 & 16.00 & 6159.783 & $0.000^{*}$ \\
\hline Sex (Male/Female) & - & - & - & - & - & $611 / 603$ & $\begin{array}{l}1420 / \\
1379\end{array}$ & $\begin{array}{l}1661 / \\
2095\end{array}$ & 32.234 & $0.000^{*}$ \\
\hline $\begin{array}{l}\text { Grade (Primary school/Junior high school/ } \\
\text { Senior high school) }\end{array}$ & $\begin{array}{l}1214 / \\
2799 / \\
3756\end{array}$ & $\begin{array}{l}160 / 451 / \\
1420 / 1661\end{array}$ & $\begin{array}{l}148 / 455 / \\
1379 / 2095\end{array}$ & 32.324 & $0.000^{*}$ & - & - & - & - & - \\
\hline Family structure & & & & 50.179 & $0.000^{*}$ & & & & 384.706 & $0.000^{*}$ \\
\hline Single parent & 794 & 346 & 448 & & & 72 & 252 & 470 & & \\
\hline Two parents & 2608 & 1339 & 1269 & & & 160 & 1064 & 1384 & & \\
\hline Three-generation & 2762 & 1350 & 1412 & & & 601 & 952 & 1209 & & \\
\hline Other & 1605 & 657 & 948 & & & 381 & 531 & 693 & & \\
\hline Occupation of parents & & & & 34.448 & $0.000^{*}$ & & & & 781.740 & $0.000^{*}$ \\
\hline Medical staff & 160 & 86 & 74 & & & 7 & 108 & 45 & & \\
\hline Police & 58 & 31 & 27 & & & 0 & 40 & 18 & & \\
\hline Civil servant & 287 & 151 & 136 & & & 7 & 164 & 116 & & \\
\hline Teacher & 195 & 102 & 93 & & & 12 & 114 & 69 & & \\
\hline Freelancer & 1838 & 906 & 932 & & & 270 & 637 & 931 & & \\
\hline Farmer & 1073 & 477 & 596 & & & 349 & 185 & 539 & & \\
\hline Researcher & 12 & 8 & 4 & & & 0 & 8 & 4 & & \\
\hline Worker & 1575 & 677 & 898 & & & 299 & 360 & 916 & & \\
\hline Self-employed & 1586 & 797 & 789 & & & 166 & 761 & 659 & & \\
\hline Others & 985 & 457 & 528 & & & 104 & 422 & 459 & & \\
\hline \multicolumn{11}{|l|}{ Family members } \\
\hline Infected (Yes/No) & $165 / 1604$ & $70 / 3622$ & $95 / 3982$ & 1.757 & 0.185 & $9 / 1205$ & $\begin{array}{l}56 / \\
2743\end{array}$ & $\begin{array}{l}100 / \\
3656\end{array}$ & 16.607 & $0.000^{*}$ \\
\hline Doctor (Yes/No) & $272 / 7497$ & $145 / 3547$ & $127 / 3950$ & 3.785 & 0.052 & $14 / 1200$ & $\begin{array}{l}166 / \\
2633\end{array}$ & $\begin{array}{l}92 / \\
3664\end{array}$ & 81.008 & $0.000^{*}$ \\
\hline Frontline worker (Yes/No) & $111 / 7658$ & $51 / 3641$ & $60 / 4017$ & 0.112 & 0.738 & 18/1196 & $\begin{array}{l}66 / \\
2733\end{array}$ & $\begin{array}{l}27 / \\
3729\end{array}$ & 30.627 & $0.000^{*}$ \\
\hline Respondent diagnosed with COVID-19 & $24 / 7745$ & $13 / 3679$ & $11 / 4066$ & 0.426 & 0.514 & $6 / 1208$ & $4 / 2795$ & $\begin{array}{l}14 / \\
3742\end{array}$ & 4.355 & 0.113 \\
\hline $\begin{array}{l}\text { Respondent had contact with suspected } \\
\text { COVID-19 patient (Yes/No) }\end{array}$ & $27 / 7742$ & $16 / 3676$ & $11 / 4066$ & 1.497 & 0.221 & $6 / 1208$ & $4 / 2795$ & $\begin{array}{l}17 / \\
3739\end{array}$ & 5.336 & $0.069^{*}$ \\
\hline $\begin{array}{l}\text { Respondent received COVID-19 therapy } \\
\text { (Yes/No) }\end{array}$ & $157 / 7612$ & $72 / 3620$ & 85/3992 & 0.178 & 0.673 & $19 / 1195$ & $\begin{array}{l}34 / \\
2765\end{array}$ & $\begin{array}{l}104 / \\
3652\end{array}$ & 21.075 & $0.000^{*}$ \\
\hline
\end{tabular}


parents (10.2\%). Others had different family structures such as living in more than three-generational households (20.7\%). The most frequent parental occupations were freelancers $(23.7 \%)$, self-employed workers (20.4\%), migrant workers $(20.3 \%)$, and farmers $(13.8 \%)$. A smaller proportion were medical workers $(2.1 \%)$, police officers $(0.7 \%)$, civil servants $(3.7 \%)$, and teachers (2.5\%).A total of 165 students had family members who had been diagnosed with COVID-19.Participants were also exposed to the virus via family members who were doctors (272 students) and frontline workers (111 students).

\section{Total CRIES-13 score}

The stress response of participants to the COVID-19 pandemic was measured based on CRIES-13 total score. A total of 1639 (21.1\%) students experienced severe symptoms of psychological stress (total score $\geq 30$; Table 2). These symptoms were more serious in senior high school students (23.3\%) compared to primary students $(20.3 \%)$ and junior high school students (18.4\%) $\left(x^{2}=23.5, p<0.001\right)$. A higher proportion of female students suffered severe psychological stress than male students $\left(22.3 \%\right.$ vs $\left.19.7 \% ; \chi^{2}=8.03, p=0.005\right)$.

To understand the degree of impact of COVID-19, we compared total CRIES-13 scores among primary school, junior high school, and senior high school students using the Kruskal-Wallis $\mathrm{H}$ test. We found a significant difference among the three groups $(H=75.512, p<0.001$; Table 2); median total CRIES-13 score was the highest for senior high school students (21), followed by the junior high school(19) and primary students (18).

After adjusting the level of significance using Bonferroni correction, a post-hoc comparison found that total CRIES-13 scores were significantly lower for primary school students $(\mathrm{Z}=-7.469$, adjusted $p<0.001)$ and junior high school students $(\mathrm{Z}=-6.616$, adjusted $p<0.001)$ than for senior high school students. However, total scores were not significantly different between primary school and junior high school students $(Z=-2.368$, adjusted $p=0.054$; Table 3). Across all three student groups, female students had higher total scores than males (median 21 vs 19; $\mathrm{Z}=-5.739, p<0.001$; Table 2).

\section{Factor scores on the CRIES-13}

We observed significant differences among the three groups of students in intrusion $(\mathrm{H}=103.14, p<0.001)$, arousal $(\mathrm{H}=183.669, p<0.001)$, and avoidance factor scores $(\mathrm{H}=45.492, p<0.001)$ (Table 2). Post-hoc comparisons of the intrusion factor showed that junior high school students had higher scores than primary students ( $\mathrm{Z}=-7.933$, adjusted $p<0.001$ ), while senior high school students had higher scores than primary students $(\mathrm{Z}=$ 10.120 , adjusted $p<0.001)$ and junior high school students $(\mathrm{Z}=-2.463$, adjusted $p=0.041$; Table 3$)$.

Pairwise comparison of the arousal factor showed that junior high school students had higher scores than primary students $(Z=-5.200$, adjusted $p<0.001)$, and senior high school students had higher scores than primary students $(Z=-12.382$, adjusted $p<0.001)$ and junior high school students $(Z=-9.214$, adjusted $p<0.001)$. In contrast, primary school students had higher avoidance factor scores than junior high school students $(Z=6.7$, adjusted $p<0.001)$ and senior high school students $(\mathrm{Z}=$ 4.327 , adjusted $p<0.001$ ), and the scores of junior high school students were lower than those of senior high school students $(\mathrm{Z}=-3.499$, adjusted $p<0.001$; Table 3$)$.

Across all three student groups, we found that female students had higher intrusion factor $(\mathrm{Z}=-6.76, p<$ $0.001)$ and arousal factor scores $(\mathrm{Z}=-3.15, p<0.001)$ than males, but lower avoidance factor scores $(Z=-3.15$, $p=0.002$; Table 2).

\section{Factors influencing individual stress response}

We performed logistic regression to determine the factors affecting total CRIES-13 scores and stress responses. Our results showed that stress response was influenced by the sex of the participant $(p=0.024)$, school grade $(p=0.001)$, past history of psychological counseling $(p<$ $0.001)$, exposure to infection via relatives $(p=0.009)$, and a recent diagnosis of COVID-19 $(p=0.006$; Table 4$)$.

Table 2 CRIES-13 scores of students, stratified by sex and grade

\begin{tabular}{|c|c|c|c|c|c|c|c|c|c|c|}
\hline & $\begin{array}{l}\text { Total } \\
(n=7769)\end{array}$ & $\begin{array}{l}\text { Male } \\
(n=3692)\end{array}$ & $\begin{array}{l}\text { Female } \\
(n=4077)\end{array}$ & $z / x^{2}$ & $\mathrm{p}$ & $\begin{array}{l}\text { Primary } \\
(n=906)\end{array}$ & $\begin{array}{l}\text { Junior High } \\
(n=2799)\end{array}$ & $\begin{array}{l}\text { Senior High } \\
(n=3756)\end{array}$ & $H / x 2$ & $\mathrm{p}$ \\
\hline \multicolumn{11}{|l|}{ Median scores } \\
\hline Total & 20 & 19 & 21 & -5.739 & $0.000^{*}$ & 18.00 & 19.00 & 21.00 & 75.512 & $0.000^{*}$ \\
\hline Intrusion factor & 8.00 & 7.00 & 8.00 & -6.759 & $0.000^{*}$ & 6.00 & 8.00 & 8.00 & 104.141 & $0.000^{*}$ \\
\hline Avoidance factor & 4.00 & 4.00 & 4.00 & -3.146 & $0.002^{*}$ & 5.00 & 4.00 & 4.00 & 45.492 & $0.000^{*}$ \\
\hline Arousal factor & 7.00 & 6.00 & 7.00 & -8.563 & $0.000^{*}$ & 5.00 & 6.00 & 8.00 & 183.669 & $0.000^{*}$ \\
\hline \multicolumn{11}{|c|}{ Distribution by total score, $\mathrm{n}(\%)$} \\
\hline$<30$ & $6130(78.9)$ & $2964(80.3)$ & $3166(77.7)$ & 8.030 & $0.005^{*}$ & $967(79.7)$ & $2283(81.60)$ & $2880(76.70)$ & 23.503 & $0.000^{*}$ \\
\hline$\geq 30$ & $1639(21.1)$ & 728 (19.7) & $911(22.3)$ & & & $247(20.3)$ & $516(18.40)$ & $876(23.30)$ & & \\
\hline
\end{tabular}


Table 3 The post-hoc comparison of CRIES-13 scores by grade

\begin{tabular}{|c|c|c|c|c|c|c|}
\hline & Primary & High & Junior & r High & Primary & $\mathrm{Hig}$ \\
\hline & $z$ & Adjusted $p$ & $z$ & Adjusted $p$ & $z$ & Adjusted $\mathrm{p}$ \\
\hline Total & -7.469 & $0.000^{*}$ & -6.616 & $0.000^{*}$ & -2.368 & 0.054 \\
\hline Intrusion factor & -10.120 & $0.000^{*}$ & -2.463 & $0.041^{*}$ & -7.933 & $0.000^{*}$ \\
\hline Avoidance factor & 4.327 & $0.000^{*}$ & -3.499 & $0.000^{*}$ & 6.7 & $0.000^{*}$ \\
\hline Arousal factor & -12.382 & $0.000^{*}$ & -9.214 & $0.000^{*}$ & -5.200 & $0.000^{*}$ \\
\hline
\end{tabular}

Individuals suffering from cold, fever, cough, nasal congestion, runny nose, sore throat, and diarrhea within 30 days of taking part in the survey also had a heightened stress response $(p=0.002)$.

\section{Discussion}

In this study, we examined the early effects of the COVID-19 pandemic on the mental and psychological health of 7769 school students in China using the CRIE S-13. Based on total CRIES-13 scores, 1639students (21.1\%) experienced symptoms of severe psychological stress, indicating an urgent need to understand the impact of such events on the mental health of children and adolescents.

Women are more likely to experience acute stress reactions and to be at higher risk of PTSD than men [25-31]. In addition, women often show higher scores than men on the invasion and avoidance factors of the CRIES-13 [32, 33]. Studies had also found that women showed more active than men in neural networks associated with fear and arousal [34]. This is consistent with our findings.

Some studies have shown that older individuals respond differently to stressful events compared with younger ones [32, 33, 35-39]. Similarly, studies of children exposed to war violence showed older children more vulnerable to stress [40]. Consistent with these results, we found that the largest proportion of students experiencing severe psychological stress were in senior high school. However, a survey of 8236 US children in grades $4-12$ at 6 months after the 9/11 attacks found that primary school students (grades 4-5) were at higher risk of post-traumatic stress symptoms than junior and senior high school students [41]. This discrepancy may reflect that different grades of students may have different degrees of stress disorder under the influence of

Table 4 Logistic regression analysis to identify factors that influence risk of severe psychological stress in students

\begin{tabular}{|c|c|c|c|c|c|}
\hline Variable & B & SE & Wald chi-square & OR $(95 \% \mathrm{Cl})$ & $p$ \\
\hline Sex (Male/Female) & 0.128 & 0.057 & 5.113 & $1.136(1.017-1.270)$ & $0.024^{*}$ \\
\hline Grade & & & 13.860 & & $0.001^{*}$ \\
\hline Primary & -0.146 & 0.083 & 3.073 & $0.864(0.735-1.017)$ & 0.080 \\
\hline Junior High & -0.234 & 0.064 & 13.200 & $0.940(0.697-0.898)$ & $0.000^{*}$ \\
\hline Occupation of parents & & & 16.827 & & 0.051 \\
\hline Medical staff & 0.179 & 0.215 & 0.689 & $1.196(0.784-1.824)$ & 0.406 \\
\hline Police & 0.280 & 0.327 & 0.732 & $1.323(0.697-2.512)$ & 0.392 \\
\hline Civil servant & 0.171 & 0.169 & 1.029 & $1.186(0.853-1.651)$ & 0.310 \\
\hline Teacher & -0.396 & 0.230 & 2.957 & $0.673(0.429-1.057)$ & 0.085 \\
\hline Freelancer & 0.183 & 0.100 & 3.341 & $1.201(0.987-1.462)$ & 0.068 \\
\hline Farmer & 0.328 & 0.111 & 8.741 & $1.388(1.117-1.725)$ & $0.003^{*}$ \\
\hline Researcher & 0.754 & 0.631 & 1.429 & $2.126(0.617-7.325)$ & 0.232 \\
\hline Worker & 0.151 & 0.104 & 2.135 & $1.163(0.950-1.425)$ & 0.144 \\
\hline Self-employed & 0.145 & 0.103 & 1.958 & $1.156(0.944-1.415)$ & 0.162 \\
\hline Psychological consultations (Yes/No) & 0.646 & 0.131 & 24.389 & $1.908(1.477-2.466)$ & $0.000^{*}$ \\
\hline Relatives infected by COVID-19 (Yes/No) & 0.451 & 0.173 & 6.779 & $1.570(1.118-2.206)$ & $0.009^{*}$ \\
\hline Respondent had contact with suspected COVID-19 patient (Yes/No) & -1.514 & 0.778 & 3.787 & $0.220(0.048-2.206)$ & $0.006^{*}$ \\
\hline Respondent diagnosed with COVID-19 (Yes/No) & 1.937 & 0.703 & 7.594 & $1.570(1.118-1.632)$ & $0.006^{*}$ \\
\hline Respondent received COVID-19 therapy (Yes/No) & 0.119 & 0.189 & 0.400 & $1.127(0.778-1.632)$ & 0.527 \\
\hline Respondent had cold, fever, cough etc. in the previous $\mathbf{3 0}$ days (Yes/No) & 0.435 & 0.142 & 9.344 & $1.544(1.169-2.040)$ & $0.002^{*}$ \\
\hline
\end{tabular}


different events. Future research should focus on more different events.

We found that senior high school students had higher scores on arousal and invasion factors on the CRIES-13, but primary school students had higher avoidance factor scores. This suggests that senior high school students are more likely to feel frightened or anxious, experience flashback reactions associated with the event, and manifest symptoms of arousal. The immaturity of the cognitive process in younger children can make them less susceptible to recurring intrusive thoughts and other cognitive impacts of trauma [42, 43]. A maladaptive cognitive style in adolescents and older children may compromise their ability to regulate emotions, rendering them more vulnerable to PTSD [44].

Based on the regression analysis, we found that the occurrence of cold-related symptoms within one month of participating in the survey significantly influenced stress response. Based on studies of the spread of various viruses, psychosocial factors are related to infection rates. C-reactive protein (CRP) is an acute-phase reactant downstream of the pro-inflammatory cytokines released during influenza infection [45]. Studies have shown that a marker of peripheral inflammation, plasma CRP, may be prospectively associated with PTSD symptom emergence, suggesting that inflammation may predispose to PTSD [46]. On the other hand, the increasing number of patients and suspected cases, and the increasing number of outbreak affected provinces and countries have elicited public worry about becoming infected [47]. As we know, the most common symptoms associated with COVID-19 are fever, cough, dyspnea, expectoration, headache, and myalgia or fatigue [48]. This is similar to the symptoms of the common cold [49]. Particularly, the relevance of perceived threat for health and life and the experienced feelings of vulnerability as mediating factors [50]. It was reported that mental health symptoms may have been common during the COVID19 outbreak among the general population in China, especially among infected individuals, people with suspected infection, and people who might have contact with patients with COVID-19 [51]. This is consistent with our research results.

Although previous studies have explored the impact of the SARS epidemic on mental health, this is the first study addressing the post-traumatic symptoms of COVID-19 on children and adolescents. Using a relatively large sample ranging widely in age, we conducted a cross-sectional study of the psychological stress status of students who were not from Hubei province at one month after the outbreak of COVID-19 in China [19]. However, this may have caused a bias since the participants were selected from schools in certain regions in China, resulting in findings that may not be generalizable across all children and adolescents. In addition, the survey involved substantially more high school students than primary school students. No strict sampling was another bias of our research, but it was really difficult and almost impossible to do so in COVID-19 crisis.

Even though the timing of the survey may help identify participants who require psychological and clinical intervention, the cross-sectional design meant that we could not assess how persistent the post-traumatic stress symptoms are. Besides, the external validity of our survey is limited, the reasons are: Firstly, most of our samples were from Sichuan. Secondly, we did not use strict sampling and used only online self-rating method without structured mental health examination. These may reduce the representativeness and reliability of the results. But it was really difficult to conduct doctor rating scale and structured mental health examination in COVID-19 pandemic crisis. Lastly, our questionnaires were filled in voluntarily. Only those students whose parents would like to let their children fill in would fill in our questionnaire. In this way, parents and students who were not interested in mental health problems couldn't be included. This, however, is also a feature of this survey as in a natural state, parents and students interested in their mental health were investigated. Our findings also may have some clinical implications for identification of children and adolescents with high risk for psychological stress after COVID-19.

\section{Conclusions}

In conclusion, our results showed that COVID-19 has placed psychological stresses on primary and secondary school students in China. These stresses are more likely to reach severe levels among female students and senior high school students.

\section{Abbreviations}

COVID-19\SARS-CoV-2: Coronavirus Disease 2019; CRIES-13: the Children's Impact of Event Scale questionnaire; PTSD: Post-Traumatic Stress Disorder; DSM-IV: the Diagnostic and Statistical Manual of Mental Disorders IV; LR: likelihood ratio; CRP: C-reactive protein

\section{Acknowledgements}

We would like to acknowledge the contribution of all of colleagues and volunteers for their support in this study.

\section{Authors' contributions}

$L Y$ conceived and designed the experiments. $H M X, H Z, L H, X L W, X W T, Y P$ W, QQ X, PX, RQ J, JZ, FD, MY Y, DL, XJ L, CL Z, WJ W, LL, HM C, WC Z, HP Z, WW helped collect the data. HM X, HZ analyzed the data. HM X, HZ and LY wrote and revised the manuscript. All authors have read and approved the manuscript.

\section{Funding}

This work was supported by the National Nature Science Foundation of China (81801357), the Science and Technology Education Program of the Sichuan Province (2020JDKP0013, 2020YFS0259), and the Chengdu Key Technology R\&D Program (2019-YF05-00284-SN). The above mentioned funding bodies had no further role in the study design, collection, analysis 
and interpretation of data; in the writing of the report; and in the decision to submit the paper for publication.

\section{Availability of data and materials}

The data that support the findings of this study are available on request from the corresponding author (Li Yin, yli009@163.com). The data are not publicly available due to privacy or ethical restrictions.

\section{Declarations}

\section{Ethics approval and consent to participate}

This study was approved by the Ethics Committee of West China Hospital of Sichuan University. The research had been performed in accordance with the Declaration of Helsinki. Written informed consents had been attained from all the participants and their guardians based on the principle of self determination. The participants'rights were fully respected and preserved in the whole process of this study.

\section{Consent for publication}

Not applicable.

\section{Competing interests}

The authors declare that they have no competing interests.

\section{Author details}

${ }^{1}$ Mental Health Center, West China Hospital of Sichuan University, No. 28 South Dianxin Street, Chengdu 610041, Sichuan, China. ${ }^{2}$ Chengdu Engineering Technical Vocational School, Chengdu 610300, Sichuan, China. ${ }^{3}$ Chengdu Vocational \& Technical College of Industry, Chengdu, Sichuan 610218, China. ${ }^{4}$ Xuchuan Middle School, Zigong 643000, Sichuan, China. ${ }^{5}$ The Fourth People's Hospital of Chengdu, Chengdu 610036, Sichuan, China. ${ }^{6}$ Jiangsu Academy of Educational Sciences, Nanjing 210013, Jiangsu, China. ${ }^{7}$ Wenquan Second Central Primary School, Donghai County, Lianyungang 222315, Jiangsu, China. ${ }^{8}$ Jiangsu Shuangdian Primary School, Rudong County, Nantong 226404, Jiangsu, China. ${ }^{9}$ The Sixth Middle School of Jianshui County, Honghe Prefecture, Jianshui County 654300, Yunnan, China. ${ }^{10}$ Egongyan Primary School, Jiulongpo District, Chongqing 404000, China. ${ }^{11}$ The 12th Elementary School of Nanyang City, Nanyang 473002, Henan, China. ${ }^{12} \mathrm{Hou}$ Central School, Xuzhou 221000, Jiangsu, China. ${ }^{13}$ The primary School Attached to SouthWest University, Chongqing 400700, China. ${ }^{14}$ Chengdu Shuangliu Yongan Middle School, Chengdu 610219, Sichuan, China. ${ }^{15}$ University-Town Hospital of Chongqing Medical University, Chongqing 401331, China. ${ }^{16}$ Institute for System Genetics, Frontiers Science Center for Disease-related Molecular Network, Chengdu 610041, Sichuan, China.

Received: 25 October 2020 Accepted: 23 June 2021

Published online: 03 July 2021

\section{References}

1. Neria Y, Nandi A, Galea S. Post-traumatic stress disorder following disasters: a systematic review. Psychol Med. 2008;38(4):467-80. https://doi.org/10.101 7/S0033291707001353.

2. Zeng EJ, Bordeaux Silverstein L. China earthquake relief: participatory action work with children. Sch Psychol Int. 2011;32(5):498-511. https://doi.org/1 $0.1177 / 0143034311402921$

3. Baum N, Rahav G, Sharon M. Heightened susceptibility to secondary traumatization: a meta-analysis of gender differences. Am J Orthop. 2014; 84(2):111-22.

4. Furr JM, Comer JS, Edmunds JM, Kendall PC. Disasters and youth: a metaanalytic examination of posttraumatic stress. J Consult Clin Psychol. 2010; 78(6):765-80. https://doi.org/10.1037/a0021482.

5. International Federation of Red Cross and Red Crescent Societies. World disasters report. Oxford: Oxford University Press; 1998.

6. Norris FH, Slone LB, Baker CK, Murphy AD. Early physical health consequences of disaster exposure and acute disaster-related PTSD. Anxiety Stress Coping. 2006;19(2):95-110. https://doi.org/10.1080/10615800600652209.

7. Becker-Blease KA, Turner HA, Finkelhor D. Disasters, victimization, and children's mental health. Child Dev. 2010;81(4):1040-52. https://doi.org/1 0.1111/j.1467-8624.2010.01453.x.
8. Adams ZW, Danielson CK, Sumner JA, McCauley JL, Cohen JR, Ruggiero KJ. Comorbidity of PTSD, major depression, and substance use disorder among adolescent victims of the spring 2011 tornadoes in Alabama and Joplin, Missouri. Psychiatry. 2015;78(2):170-85. https://doi.org/10.1080/00332747.201 5.1051448 .

9. Kenardy J, Smith A, Spence SH, Lilley PR, Newcombe P, Dob R, et al. Dissociation in children's trauma narratives: an exploratory investigation. J Anxiety Disord. 2007;21(3):456-66. https://doi.org/10.1016/j.janxdis.2006.05.007.

10. Pfefferbaum B. Posttraumatic stress disorder in children: a review of the past 10 years. J Am Acad Child Adolesc Psychiatry. 1997;36(11):1503-11.

11. Pynoos RS, Steinberg AM, Layne CM, Briggs EC, Ostrowski SA, Fairbank JA DSM-V PTSD diagnostic criteria for children and adolescents: a developmental perspective and recommendations. J Trauma Stress. 2009; 22(5):391-8. https://doi.org/10.1002/jts.20450.

12. Fairbank JA, Fairbank DW. Epidemiology of child traumatic stress. Curr Psychiatry Rep. 2009;11(4):289-95. https://doi.org/10.1007/s11920-009-0042-9.

13. Alisic E, van der Schoot TA, van Ginkel JR, Kleber RJ. Looking beyond posttraumatic stress disorder in children: posttraumatic stress reactions, posttraumatic growth, and quality of life in a general population sample. J Clin Psychiatry. 2008;69(9):1455-61. https://doi.org/10.4088/JCP.v69n0913.

14. Laaser $\mathrm{U}$, Brand $\mathrm{H}$. Global health in the 21 st century. Glob Health Action 2014;7(1):23694. https://doi.org/10.3402/gha.v7.23694.

15. Cheng SK, Tsang JS, Ku KH, Wong CW, Ng YK. Psychiatric complications in patients with severe acute respiratory syndrome (SARS) during the acute treatment phase: a series of 10 cases. Br J Psychiatry. 2004;184(4):359-60. https://doi.org/10.1192/bjp.184.4.359.

16. Chua SE, Cheung V, MCAlonan GM, Cheung C, Wong JW, Cheung EP, et al. Stress and psychological impact on SARS patients during the outbreak. Can J Psychiatr. 2004:49(6):385-90. https://doi.org/10.1177/070674370404900607.

17. Cheng SK, Wong CW, Tsang J, Wong KC. Psychological distress and negative appraisals in survivors of severe acute respiratory syndrome (SARS). Psychol Med. 2004;34(7):1187-95. https://doi.org/10.1017/S0033291704002272

18. Wu KK, Chan SK, Ma TM. Posttraumatic stress, anxiety, and depression in survivors of severe acute respiratory syndrome (SARS). J Trauma Stress. 2005; 18(1):39-42. https://doi.org/10.1002/jts.20004.

19. Huang C, Wang Y, Li X, Ren L, Zhao J, Hu Y, et al. Clinical features of patients infected with 2019 novel coronavirus in Wuhan, China. Lancet. 2020;395(10223):497-506. https://doi.org/10.1016/S0140-6736(20)30183-5.

20. Guerriero RM, Pier DB, de Gusmao CM, Bernson-Leung ME, Maski KP, Urion DK, et al. Increased pediatric functional neurological symptom disorders after the Boston marathon bombings: a case series. Pediatr Neurol. 2014; 51(5):619-23. https://doi.org/10.1016/j.pediatrneurol.2014.07.011.

21. Lau JT, Yeung NC, Yu XN, Zhang J, Mak WW, Lui WW, et al. Validation of the Chinese version of the Children's revised impact of event scale (CRIES) among Chinese adolescents in the aftermath of the Sichuan earthquake in 2008. Compr Psychiatry. 2013;54(1):83-90. https://doi.org/10.1016/j. comppsych.2012.06.007.

22. Perrin S, Meiser-Stedman $R$, Smith $P$. The children's revised impact of event scale (CRIES):validity as a screening instrument for PTSD. Behav Cogn Psychother. 2005;33:487-98.

23. Dyregrov A, Kuterovac G, Barath A. Factor analysis of the impact of event scale with children in war. Scand J Psychol. 1996;37(4):339-50. https://doi. org/10.1111/j.1467-9450.1996.tb00667.x.

24. Zhang N, Zhang Y, Wu K, Zhu Z, Dyregrov A. Factor structure of the Children's revised impact of event scale among children and adolescents who survived the 2008 Sichuan earthquake in China. Scand J Psychol. 2011; 52(3):236-41. https://doi.org/10.1111/j.1467-9450.2010.00867.x.

25. Pine DS, Cohen JA. Trauma in children and adolescents: risk and treatment of psychiatric sequelae. Biol Psychiatry. 2002;51(7):519-31. https://doi.org/1 0.1016/S0006-3223(01)01352-X

26. Lai J, Ma S, Wang Y, Cai Z, Hu J, Wei N, et al. Factors associated with mental health outcomes among health care workers exposed to coronavirus disease 2019. JAMA Netw Open. 2020;3(3):e203976. https://doi.org/10.1001/ jamanetworkopen.2020.3976.

27. Liu N, Zhang F, Wei C, Jia Y, Shang Z, Sun L, et al. Prevalence and predictors of PTSS during COVID-19 outbreak in China hardest-hit areas: gender differences matter. Psychiatry Res. 2020;287:112921. https://doi.org/10.1016/j. psychres.2020.112921.

28. Christiansen DM, Hansen M. Accounting for sex differences in PTSD: a multivariable mediation model. Eur J Psychotraumatol. 2015;6(1):26068. https:// doi.org/10.3402/ejpt.v6.26068. 
29. Alisic E, Jongmans MJ, van Wesel F, Kleber RJ. Building child trauma theory from longitudinal studies: a meta-analysis. Clin Psychol Rev. 2011;31(5):73647. https://doi.org/10.1016/j.cpr.2011.03.001.

30. Ma X, Liu X, Hu X, Qiu C, Wang Y, Huang Y, et al. Risk indicators for posttraumatic stress disorder in adolescents exposed to the 5.12 Wenchuan earthquake in China. Psychiatry Res. 2011;189(3):385-91. https://doi.org/10.1 016/j.psychres.2010.12.016.

31. Perrin M, Vandeleur CL, Castelao E, Rothen S, Glaus J, Vollenweider P, et al. Determinants of the development of post-traumatic stress disorder, in the general population. Soc Psychiatry Psychiatr Epidemiol. 2014;49(3):447-57. https://doi.org/10.1007/s00127-013-0762-3.

32. Hampel P, Petermann F. Age and gender effects on coping in children and adolescents. Journal of Youth and Adolescence. 2005;34(2):73-83. https:// doi.org/10.1007/s10964-005-3207-9.

33. Tekin A, Karadag $H$, Suleymanoglu M, Tekin M, Kayran Y, Alpak G, et al. Prevalence and gender differences in symptomatology of posttraumatic stress disorder and depression among Iraqi Yazidis displaced into Turkey. Eur J Psychotraumatol. 2016;7(1):28556. https://doi.org/10.3402/ejpt.v7.2 8556.

34. Felmingham K, Williams LM, Kemp AH, Liddell B, Falconer E, Peduto A, et al. Neural responses to masked fear faces: sex differences and trauma exposure in posttraumatic stress disorder. J Abnorm Psychol. 2010;119(1):241-7. https://doi.org/10.1037/a0017551.

35. Ahmad N, Hussain S, Munir N. A tale of internal displacement: post traumatic stress disorder (PTSD) among school students in swat, Pakistan. Rawal Med J. 2018;43(3):511-4.

36. Vindegaard N, Benros ME. COVID-19 pandemic and mental health consequences: systematic review of the current evidence. Brain Behav Immun. 2020;89:531-42. https://doi.org/10.1016/j.bbi.2020.05.048.

37. Yun-Li YE, Ya L, Min C. Trajectory and the related factors of PTSD in secondary school students after earthquake. Chin J Sch Health. 2011;32:1667.

38. Felton JW, Cole DA, Martin NC. Effects of rumination on child and adolescent depressive reactions to a natural disaster: the 2010 Nashville flood. J Abnorm Psychol. 2013;122(1):64-73. https://doi.org/10.1037/a00293 03

39. Xu W, Yuan G, Liu Z, Zhou Y, An Y. Prevalence and predictors of PTSD and depression among adolescent victims of the summer 2016 tornado in Yancheng City. Arch Psychiatr Nurs. 2018;32(5):777-81. https://doi.org/10.101 6/j.apnu.2018.04.010

40. Ulset VS, Czajkowski NO, Kraft B, Kraft P, Wikenius E, Kleppesto TH, et al. Are unpopular children more likely to get sick? Longitudinal links between popularity and infectious diseases in early childhood. PLoS One. 2019;14(9): e0222222. https://doi.org/10.1371/journal.pone.0222222.

41. Hoven CW, Duarte CS, Lucas CP, Wu P, Mandell DJ, Goodwin RD, et al Psychopathology among New York city public school children 6 months after September 11. Arch Gen Psychiatry. 2005:62(5):545-52. https://doi. org/10.1001/archpsyc.62.5.545.

42. Galea S, Nandi A, Vlahov D. The epidemiology of post-traumatic stress disorder after disasters. Epidemiol Rev. 2005;27(1):78-91. https://doi.org/10.1 093/epirev/mxi003.

43. Guthrie R, Bryant R. Attempting suppression of traumatic memories over extended periods in acute stress disorder. Behav Res Ther. 2000:38(9):899_ 907. https://doi.org/10.1016/S0005-7967(99)00120-5.

44. Ehlers A, Mayou RA, Bryant B. Cognitive predictors of posttraumatic stress disorder in children: results of a prospective longitudinal study. Behav Res Ther. 2003;41(1):1-10. https://doi.org/10.1016/S0005-7967(01)00126-7.

45. Vasileva D, Badawi A. C-reactive protein as a biomarker of severe $\mathrm{H} 1 \mathrm{~N}$ influenza. Inflamm Res. 2019;68(1):39-46. https://doi.org/10.1007/s00011-01 8-1188-x.

46. Eraly SA, Nievergelt CM, Maihofer AX, Barkauskas DA, Biswas N, Agorastos A, et al. Assessment of plasma C-reactive protein as a biomarker of posttraumatic stress disorder risk. JAMA Psychiatry. 2014;71(4):423-31. https://doi.org/10.1001/jamapsychiatry.2013.4374.

47. Bao Y, Sun Y, Meng S, Shi J, Lu L. 2019-nCoV epidemic: address mental health care to empower society. Lancet. 2020;395(10224):e37-8. https://doi. org/10.1016/S0140-6736(20)30309-3

48. Acter T, Uddin N, Das J, Akhter A, Choudhury TR, Kim S. Evolution of severe acute respiratory syndrome coronavirus 2 (SARS-CoV-2) as coronavirus disease 2019 (COVID-19) pandemic: a global health emergency. Sci Total Environ. 2020;730:138996. https://doi.org/10.1016/j.scitotenv.2020.138996.
49. Halstead P, Arbuckle R, Marshall C, Zimmerman B, Bolton K, Gelotte C. Development and content validity testing of patient-reported outcome items for children to self-assess symptoms of the common cold. Patient. 2020;13(2):235-50. https://doi.org/10.1007/s40271-019-00404-8.

50. Lee SM, Kang WS, Cho AR, Kim T, Park JK. Psychological impact of the 2015 MERS outbreak on hospital workers and quarantined hemodialysis patients. Compr Psychiatry. 2018;87:123-7.

51. Shi L, Lu ZA, Que JY, Huang XL, Liu L, Ran MS, et al. Prevalence of and risk factors associated with mental health symptoms among the general population in China during the coronavirus disease 2019 pandemic. JAMA Netw Open. 2020;3(7):e2014053. https://doi.org/10.1001/jamanetworkopen.2 020.14053 .

\section{Publisher's Note}

Springer Nature remains neutral with regard to jurisdictional claims in published maps and institutional affiliations.
Ready to submit your research? Choose BMC and benefit from:

- fast, convenient online submission

- thorough peer review by experienced researchers in your field

- rapid publication on acceptance

- support for research data, including large and complex data types

- gold Open Access which fosters wider collaboration and increased citations

- maximum visibility for your research: over $100 \mathrm{M}$ website views per year

At BMC, research is always in progress.

Learn more biomedcentral.com/submissions 